\title{
UV Spectrophotometric Method for the Estimation of Roflumilast in Human Serum
}

Raveendra $\mathrm{BG}^{1^{*}}$, Kiran $\mathrm{SSB}^{2}$, Kumari $\mathrm{VM}^{2}$, Jyothi $\mathbf{R K}^{2}$ and Bhavani $\mathrm{DM}^{3}$

${ }^{1}$ AKRG College of Pharmacy, Nallajerla-534112, Andhra Pradesh, India

2OTPR Institute, J N T U, Ananthapuramu-515002, Andhra Pradesh, India

${ }^{3}$ DCRMP College, Inkollu-532167, Andhra Pradesh, India

*Corresponding author: Raveendra BG, Department of Pharmaceutical Analysis and Quality Assurance, Nallajerla, Tel: + 919030102494; E-mail: upendragudimitla@gmail.com

Received date: May 17, 2016; Accepted date: Jun 28, 2016; Published date: Jun 30, 2016

Copyright: (c) 2016 Raveendra BG, et al. This is an open-access article distributed under the terms of the Creative Commons Attribution License, which permits unrestricted use, distribution, and reproduction in any medium, provided the original author and source are credited.

\begin{abstract}
Ultra violet spectrophotometric method for the estimation roflumilast in spiked human serium. The present study was spectrophotometric estimation of roflumilast in spiked human serum is based on measurement at the maximum wavelength $248 \mathrm{~nm}$ using $0.2 \mathrm{M} \mathrm{Hcl}$ as a solvent. The roflumilast stock solution was prepared with distilled water to produse calibration curve. The standard solution of roflumilast shows absorption maxima at $248 \mathrm{~nm}$. The roflumilast obeyed beer lamberts law in the concentration range of $40-88 \mu \mathrm{g} / \mathrm{ml}$ with regression 0.9987 at $248 \mathrm{~nm}$. The overall percentage recovery of roflumilast was found to be $99.52 \%$ which reflects that the method was free from the interference. The \% RSD values of intra day and inter day precision was found to be 0.031 and $0.046 \%$ respectively, which is less than 2 and hence this method is precise. The values of LOD and LOQ were found to be 0.783 and $2.375 \mu \mathrm{g} / \mathrm{ml}$, respectively and it indicates this method was sensitive.
\end{abstract}

Keywords: Serum; Roflumilast; Method development; and precise for estimation of roflumilast in spiked human serum by Spectrophotometric using UV spectroscopy.

\section{Introduction}

Roflumilast (Figure 1) is a chemically3-(cyclopropylmethoxy)-N(3,5-dichloropyridin-4-yl)-4-(difluoromethoxy) benzamide and it is a selective, long acting phosphodiesterase-4 inhibitor.<smiles>O=C(Nc1c(Cl)cncc1Cl)c1ccc(OC(F)F)c(OCC2CC2)c1</smiles>

Figure 1: Chemical structure of roflumilast.

Roflumilast was used for the treatment of chronic obstractive pulmonary disease $[1,2]$ and roflumilast was freely soluble in methanol and lower alcohols. A few spectrophotometric [3-5] and HPLC [6,7] methods were reported earlier for the estimation of roflumilast in bulk and pharmaceutical dosage forms and this method was validated as per ICH guidelines [8]. Although no method was reported for the estimation of roflumilast in serum in pharmaceutical dosage forms. The present study was authors reported a simple, sensitive, accurate

\section{Experimental}

\section{Instrument}

ElicoSL164 UV-Visible spectrophotometer with double beam detector configuration. The above instruments had automatic wavelength accuracy $0.1 \mathrm{~nm}$ and matched quartz cells and Weighing balance (Elico, India).

\section{Materials}

Blank human serum, Roflumilast sample (99.90\% purity) was purchased from Spectrum Pharma Research Solutions, Hyderabad, India. Hydrochloiric acid and water (HPLC grade) obtained from Qualigens Fine Chemicals, Mumbai, India.

\section{Method development}

Preparation of standard solution: A standard stock solution was prepared by accurately weighed $1000 \mathrm{mg}$ of roflumilast in $1000 \mathrm{ml}$ of volumetric flask and dissolved in $0.2 \mathrm{M}$ of $\mathrm{Hcl}$ to obtain a concentration $1000 \mu \mathrm{g} / \mathrm{ml}$. Further diluting $2.5 \mathrm{ml}$ of stock solution to $25 \mathrm{ml}$ with distilled water to get desired concentration of $25 \mu \mathrm{g} / \mathrm{ml}$. Further diluting $0.4 \mathrm{ml}$ of stock solution to $100 \mathrm{ml}$ with distilled water to get desired concentration of $40 \mu \mathrm{g} / \mathrm{ml}$.

Selection of wavelength for analysis of Roflumilast: Accurately measured $0.4 \mathrm{ml}$ of standard stock-III was transferred in to $100 \mathrm{ml}$ volumetric flask and diluted to $100 \mathrm{ml}$ to give concentration of $40 \mu \mathrm{g} / \mathrm{ml}$ and it was used for initial spectral scan in the range of $200-400 \mathrm{~nm}$ to detect maximum wavelength and further dilutions for linearity was 
Citation: Raveendra BG, Kiran SSB, Kumari VM, Jyothi RK and Bhavani DM (2016) UV Spectrophotometric Method for the Estimation of

prepared from the stock solution by allegation method. The maximum wave length was found at $248 \mathrm{~nm}$.

Preparation of calibration plot: $5 \mathrm{ml}$ of serum was taken in a $250 \mathrm{ml}$ separating funnel and spiked with $10 \mathrm{ml}$ aqueous solution contains $40-88 \mu \mathrm{g} / \mathrm{ml}$ of Roflumilast $(40,50,64,72,88 \mu \mathrm{g} / \mathrm{ml})$.

To the same solution add $20 \mathrm{ml}$ of methyl acetate. The content was shaken for $15 \mathrm{~min}$ and the liquids were allowed to separate in to two immiscible phases.

The lower aqueous layer was discarded and the upper organic layer was collected in a beaker. Finally water free organic layer was transferred in to a dried beaker and evaporated to dryness on a hot water bath. The dry residue was reconstituted with $2 \mathrm{ml}$ of $0.2 \mathrm{M}$ HCL and transferred in to a $25 \mathrm{ml}$ calibrated flask. The volume was making with water.

\section{Method validation}

The developed method was validated for various parameters like linearity, precision, accuracy, limit of detection, limit of quantitation, robustness and ruggedness according to ICH guidelines.

Linearity: The manifest linear relationship in the range of 40-88 $\mu \mathrm{g} / \mathrm{ml}$ of roflumilast.

Precision: The intra day precision analysed in the same day and inter day precision analysed for three consecutive days. The results was indicated by calculated percent relative standard deviation.

Accuracy: Recovery study was carried out at three different levels $50 \%, 100 \%$ and $150 \%$. The percentage recovery was calculated as mean \pm standard deviation.

Limit of detection (LOD): Formula for measuring of limit of detection.

$\mathrm{LOD}=3.3 \sigma / \mathrm{S}$

Where,

$\sigma=$ Standard deviation

$\mathrm{S}=$ Slope

Limit of quantification (LOQ): Formula for measuring of limit of quantification.

$\mathrm{LOD}=10 \sigma / \mathrm{S}$

Where,

$\sigma=$ Standard deviation

$\mathrm{S}=$ Slope

Robustness: The robustness of an analytical procedure is a measure of its capacity unaffected by a small.

Ruggedness: The ruggedness to express in condition with variations like different analyst, different instruments and different days.

\section{Results and Discussion}

\section{Selection of wavelength}

The spectra of roflumilast in $0.2 \mathrm{M}$ hydrochloric acid showed absorption at $248 \mathrm{~nm}$ shown in Figure 2.

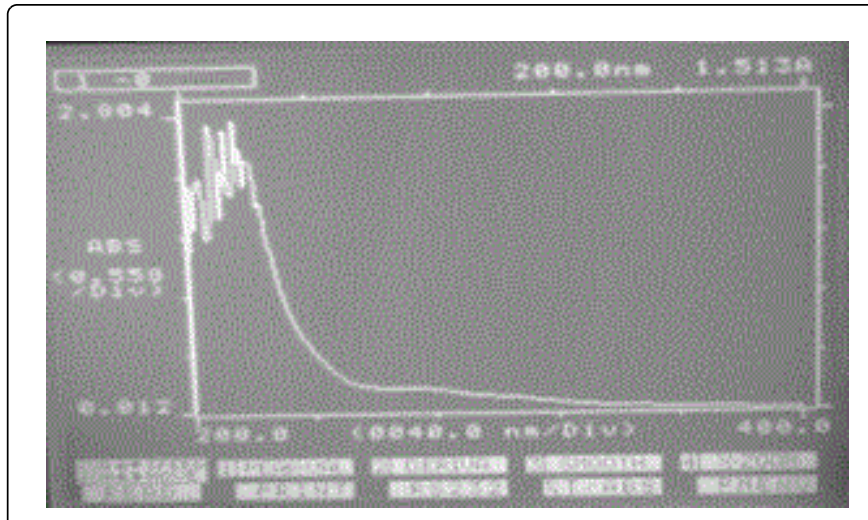

Figure 2: UV spectrum of roflumilast.

\section{Linearity}

The linearity for the proposed method was investigated at five concentration levels $(40-88 \mu \mathrm{g} / \mathrm{ml})$ of reference standard roflumilast. The linearity was shown in Table 1 and Figure 3.

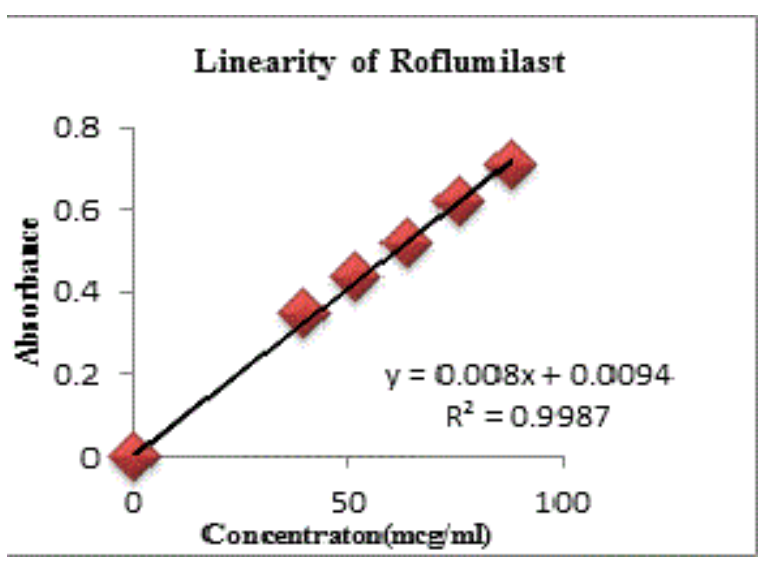

Figure 3: Linearity plot of roflumilast.

\begin{tabular}{|l|l|l|}
\hline S.No. & Concentration $(\mathbf{m c g} / \mathbf{m l})$ & Absorbance \\
\hline 1 & 40 & 0.345 \\
\hline 2 & 52 & 0.472 \\
\hline 3 & 64 & 0.521 \\
\hline 4 & 72 & 0.643 \\
\hline 5 & 88 & 0.712 \\
\hline
\end{tabular}

Table 1: Linearity data of roflumilast.

\section{Precision}

The percent RSD value of intra day and inter day precision were found to be 0.031 and 0.046 respectively, as shown in Table 2 .

Sample number Assay of roflumilast

Assay of roflumilast 
Citation: Raveendra BG, Kiran SSB, Kumari VM, Jyothi RK and Bhavani DM (2016) UV Spectrophotometric Method for the Estimation of Roflumilast in Human Serum. Pharm Anal Acta 7: 487. doi:10.4172/2153-2435.1000487

Page 3 of 4

\begin{tabular}{|l|l|l|}
\hline & Intra-day precision & Inter-day precision \\
\hline 1 & 99.13 & 99.13 \\
\hline 2 & 99.11 & 99.18 \\
\hline 3 & 99.09 & 99.08 \\
\hline 4 & 99.07 & 99.08 \\
\hline 5 & 99.05 & 99.10 \\
\hline 6 & 99.12 & 99.05 \\
\hline Mean & 99.09 & 99.10 \\
\hline \%RSD & 0.031 & 0.046 \\
\hline
\end{tabular}

Table 2: Precision data of roflumilast.

\section{Accuracy}

The percentage of recovery of roflumilast was found to be $99.82 \%$, shown in Table 3.

\begin{tabular}{|l|l|l|l|l|l|l|}
\hline $\begin{array}{l}\text { Ingredien } \\
\mathbf{t}\end{array}$ & $\begin{array}{l}\text { Tablet } \\
\text { amount } \\
\text { (mg/ml) }\end{array}$ & $\begin{array}{l}\text { Level of } \\
\text { Additio } \\
\mathbf{n}(\%)\end{array}$ & $\begin{array}{l}\text { Amoun } \\
\mathbf{t} \\
\text { added } \\
\mathbf{( m g )}\end{array}$ & $\begin{array}{l}\text { Drug } \\
\text { found } \\
\text { (mg/ml) }\end{array}$ & $\begin{array}{l}\text { \% } \\
\text { Recover } \\
\mathbf{y}\end{array}$ & $\begin{array}{l}\text { Average \% } \\
\text { recovery }\end{array}$ \\
\hline $\begin{array}{l}\text { Roflumila } \\
\text { st }\end{array}$ & 500 & 50 & 5 & 4.97 & 99.40 & \\
\hline & 500 & 100 & 10 & 9.99 & 99.90 & $99.52 \pm 0.13$ \\
\hline & 500 & 150 & 15 & 14.89 & 99.26 & \\
\hline
\end{tabular}

Table 3: Accuracy data of roflumilast.

\section{Limit of detection}

The limit of Detection (LOD) value obtained was $0.783 \mu \mathrm{g} / \mathrm{ml}$, it indicates the high sensitivity of the proposed method Table 4.

\begin{tabular}{|l|l|l|}
\hline S.No & Parameter & Roflumilast \\
\hline 1 & Absorption maxima(nm) & 248 \\
\hline 2 & Linearity $(\mathrm{mcg} / \mathrm{ml})$ & $40-88$ \\
\hline 3 & Standard Regression Equation & $\mathrm{Y}=0.008 \mathrm{X}-0.0094$ \\
\hline 4 & Correlation Coefficient (r2) & 0.9987 \\
\hline 5 & Molar extinction coefficient & 0.008 \\
\hline 6 & Accuracy (\%recovery \pm SD) & $99.52 \pm 0.13$ \\
\hline 7 & $\begin{array}{l}\text { Precision } \\
\text { Sandell's Sensitivity } \\
\text { (mg/cm2/0.001absorbance } \\
\text { unit)8 }\end{array}$ & $\begin{array}{l}99.09 \% \text { (Intra-day precision) and } \\
99.10 \% \text { (Inter-day precision) }\end{array}$ \\
\hline 9 & LOD (mg/ml) & 0.155 \\
\hline 10 & \begin{tabular}{l} 
LOQ (mg/ml) \\
\hline
\end{tabular} & 2.37 \\
\hline
\end{tabular}

\section{Limit of quantitation}

The limit of quantitation (LOQ) obtained was $2.375 \mu \mathrm{g} / \mathrm{ml}$, it indicates the high sensitivity of the proposed method.

\section{Robustness}

The percent RSD of roflumilast was found to be 0.966 . The robustness of results were shown in Table 5.

\begin{tabular}{|l|l|}
\hline S.No. & Roflumilast \\
\hline Assay-1 & 99.13 \\
\hline Assay-2 & 99.17 \\
\hline Assay-3 & 99.16 \\
\hline Assay-4 & 99.12 \\
\hline Assay-5 & 99.19 \\
\hline Assay-6 & 99.2 \\
\hline Mean & 99.17 \\
\hline S.D & 0.09 \\
\hline \%RSD & 0.091 \\
\hline
\end{tabular}

Table 5: Robustness data of roflumilast.

\section{Ruggedness}

Percent relative standard deviation of roflumilast was found to be 0.719. The ruggedness of results were shown in Table 6 .

\begin{tabular}{|l|l|}
\hline S.No & Roflumilast \\
\hline Assay-1 & 99.13 \\
\hline Assay-2 & 99.18 \\
\hline Assay-3 & 99.19 \\
\hline Assay-4 & 99.16 \\
\hline Assay-5 & 99.09 \\
\hline Assay-6 & 99.15 \\
\hline Mean & 99.15 \\
\hline S.D & 0.036 \\
\hline \%RSD & 0.033 \\
\hline
\end{tabular}

Table 6: Ruggedness data of Roflumilat.

\section{Conclusion}

The proposed method was simple, linear, precise, accurate and robust developed for the estimation of roflumilast in human serum by using UV spectroscopy. The method was validated as per the ICH guidelines. Hence, The present method can be adopted for routine in quality control and reaserch industries.

Table 4: Validation parameters of roflumilast. 
Citation: Raveendra BG, Kiran SSB, Kumari VM, Jyothi RK and Bhavani DM (2016) UV Spectrophotometric Method for the Estimation of Roflumilast in Human Serum. Pharm Anal Acta 7: 487. doi:10.4172/2153-2435.1000487

Page 4 of 4

\section{References}

1. Herbert C, Hettiaratchi A, Webb DC, Thomas PS, Foster PS, et al. (2008) Suppression of cytokine expression by roflumilast and dexamethasone in a model of chronic asthma. Clin Exp Allergy 38: 847-856.

2. Hohlfed JM, Schoenfeld K, Lavae-Mokhtari M, Schaumann F, Mueller M, et al. (2008) Roflumilast attenuates inflammation upon segmental end toxin challenge in healthy subjects a randomized placebo controlled trail. Pulm Pharmacol Ther 21: 616-623.

3. Ladani JJ, Bhimani RD, Vyas KB, Nimavat KS (2012) Method development and validation of roflumilast in tablet dosage form by uv spectrophotometry. JAM 2: 369-374.

4. Krishna RP, Desai DG, Aarti Z, Kumar AS (2013) Development and validation of uv spectroscopy method for the estimation of roflumilast in bulk and tablet dosage form. Pharma Science Monitor 4: 275-280.
5. Patel PU, Patel UB (2016) Development and validation of spectrophotometric method for simultaneous determination of roflumilast and salmeterol in synthetic mixture. IJPPR 5: 68-77.

6. Ladani JJ, Bhimani RD, Vyas KB, Nimavat KS. (2013) Analytical method development and validation of RP HPLC for estimation of roflumilast in bulk drug and tablet dosage form. International Journal for Pharmaceutical Research Scholars 1: 28-32.

7. Jujjuri P, Regunta H, Diyi D (2013) A novel rp-hplc method for the quantification of roflumilast in formulations. International Journal of Science and Technology 7: 388-394.

8. (2005) ICH Harmonised Tripartite Guideline, vlidation of analytical procedures:text methodology, Q2(R1), InternationalConferenceon Harmonization, Geneva, 1-13. 